\title{
EVALUASI DALAM PEMBELAJARAN BAHASA ARAB
}

\author{
Ubaid Ridho \\ Universitas Islam Negeri Syarif Hidayatullah \\ E-Mail:ubaid.ridlo@uinjkt.ac.id
}

\begin{abstract}
Abstrack
This article explains the importance of evaluation as one of the learning components, particularly in Arabic teaching and learning. In the learning process there are two main activities, namely learning done by the students and teaching done by the teacher, the two activities are to achieve the objectives set out in the lesson plan. In this article, readers are invited by the author to discuss various matters related to the evaluation of Arabic learning, such as the objectives and principles of evaluation, the variety of evaluation, and the signs in the preparation of test equipment, whether test or non test techniques.
\end{abstract}

Keyword: Evaluation, learning, model, technique, test, and non test

\begin{abstract}
Abstrak
Artikel ini menjelaskan tentang pentingnya evaluasi sebagai salah satu komponen pembelajaran, utamanya dalam kegiatan belajar mengajar bahasa Arab. Dalam proses pembelajaran ada dua kegiatan utama, yaitu belajar yang dilakukan oleh peserta didik dan mengajar yang dilakukan oleh guru, dua kegiatan tersebut adalah untuk mencapai tujuan yang telah ditetapkan dalam rencana pembelajaran. Dalam artikel ini, pembaca diajak penulis untuk berdiskusi tentang berbagai hal terkait evaluasi pembelajaran bahasa Arab, diantaranya adalah tujuan dan prinsip evaluasi, ragam evaluasi, dan rambu-rambu dalam penyusunan alat tes, baik teknik tes atau non tes.
\end{abstract}

Kata Kunci: Evaluasi, pembelajaran, model, teknik, tes, dan non tes 


\section{A. Pendahuluan}

Pembelajaran merupakan suatu proses belajar yang berulangulang dan menyebabkan adanya perubahan perilaku yang disadari dan cenderung bersifat tetap. ${ }^{1}$ Demikian juga Suwarna Pringgawidagda, menuturkan bahwa pembelajaran adalah suatu perubahan perilaku yang relatif tetap dan merupakan hasil praktik yang diulang-ulang. ${ }^{2}$ Dalam proses pembelajaran ada dua kegiatan utama, yaitu belajar yang harus dilakukan oleh peserta didik dan mengajar yang dilakukan oleh guru yang yang arah dua kegiatan tersebut adalah untuk mencapai tujuan yang telah ditentukan yang wujudnya berupa hasil belajar baik yang bersifat kognitif, afektif, dan psikomotorik. ${ }^{3}$

Pengajaran bahasa Arab sebagai bahasa asing sudah sejak lama diajarkan di Indonesia baik secara formal maupun non formal mulai dari Ibtidaiyyah hingga perguruan tinggi. Hal ini disebabkan karena bahasa Arab berfungsi sangat besar bagi masyarakat Indonesia, yaitu sebagai bahasa keagamaan, kebudayaan, ilmu pengetahuan, juga sebagai bahasa komunikasi dengan bangsa-bangsa Arab.

Pelajaran bahasa Arab merupakan pelajaran inti sejak berdirinya lembaga pendidikan pesantren dan madrasah. berbeda dengan di pesantren yang menempatkan pelajaran bahasa Arab dalam proporsi yang sangat besar-khususnya di pesantren-pesantren yang memang sejak berdirinya sangat menekankan pengajaran nahwu-sharaf-mata pelajaran bahasa Arab di madrasah dimasukkan ke dalam kelompok mata pelajaran pendidikan agama yang terdiri dari al-Qur'an-Hadits, Akidah-Akhlak, Fikih, Sejarah Kebudayaah/Peradaban Islam, dan bahasa Arab. pelajaran bahasa Arab di madrasah tidak dikelompokkan ke dalam kelompok pendidikan dasar umum, artinya bukan sebagai bahasa asing yang lain (seperti bahasa Inggris), melainkan sebagai bahasa agama Islam, yang wajib dipelajari untuk memahami al-Qur'an, Hadits Nabi dan buku agama Islam yang berbahasa Arab. ${ }^{4}$

${ }^{1}$ Muhammad Thobroni, Arif Mustofa, Belajar Dan Pembelajaran, (Yogyakarta: Ar-Ruz Media, 2013), h. 21

2 Suwarna Pringgawidagda, Strategi Penguasaan Berbahasa, (Yogyakarta: Adicita Karya Nusa, 2002), h. 20

${ }^{3}$ Sukiman, Pengembangan Sistem Evaluasi, (Yogyakarta: Insan Madani, 2012)

h. 11

${ }^{4}$ H.D. Hidayat, "Pengajaran Bahasa Arab Di Indonesia, Masalah Dan Cara Mengatasinya", Makalah, (Jakarta: Seminar Pengembangan Pengajaran Bahasa Arab Di 
Bahasa Arab hingga kini masih dianggap oleh sebagian besar peserta didik sebagai bahasa yang sulit dipelajari, bahkan dipandang sebagai bidang studi yang tidak disukai. Begitu pula dalam hal pelaksanaan pengajarannya, banyak permasalahan-permasalahan yang dihadapi, mulai dari tingkat dasar hingga tingkat perguruan tinggi.

Evaluasi adalah kegiatan identifikasi untuk melihat apakah suatu program yang telah direncanakan telah tercapai atau belum, berharga atau tidak, dan dapat pula untuk melihat tingkat efisiensi pelaksanaannya. ${ }^{5}$ Pengertian lain evaluasi adalah kegiatan untuk mengumpulkan informasi tentang bekerjanya sesuatu dan kemudian informasi tersebut digunakan untuk menentukan alternatif yang tepat ketika mengambil keputusan. ${ }^{6}$ Evaluasi dapat juga diartikan sebagai proses menilai sesuatu berdasarkan kriteria atau tujuan yang ditetapkan sebelumnya, yang selanjutnya diikuti dengan pengambilan keputusan atas obyek yang dievaluasi. ${ }^{7}$

Oleh karena pentingnya evaluasi dalam pembelajaran, maka dalam artikel ini penulis akan memaparkan tentang ragam evaluasi, tujuan dan prinsip evaluasi pembelajaran, alat dan teknik evaluasi pembelajaran bahasa Arab.

\section{B. Evaluasi Pembelajaran}

Dalam penyelenggaraan pengajaran pada umumnya - termasuk di dalam pengajaran bahasa-evaluasi memiliki tempat dan peranan yang terkait langsung, dan bahkan merupakan bagian tak terpisahkan dari pengajaran itu. Dalam teori penyusunan dan perencanaan pengajaran, pengajaran digambarkan sebagai suatu proses yang terdiri dari tiga komponen utama yang tidak terpisahkan satu dengan yang lain. Ketiga komponen itu adalah tujuan pengajaran, pelaksanaan pengajaran dan penilaian hasil pengajaran. Ketiganya memiliki hubungan yang erat satu sama lain, baik secara langsung dalam hubungan sebab akibat, maupun secara tidak langsung dalam bentuk umpan balik. ${ }^{8}$ Hubungan

Indonesia, 1986), H. 6

${ }^{5}$ Sri Wahyuni, Abd Syakur Ibrahim, Asessmen Pmebelajaran Bahasa,(Bandung: Refika Aditama, 2012), h. 3

${ }^{6}$ Suharsimi Arikunto, Cepi Safruddin Abdul Jabar, Evaluasi Program Pendidikan: Pedoman Teoritis Praktis Bagi Praktisi Pendidikan, (Jakarta: Bumi Aksara, 2007), h.1-2

${ }^{7}$ Djaali dan Pudji Muljono, Pengukuran Dalam Bidang Pendidikan (Jakarta: PT. Grasindo, 2008), h. 1

${ }^{8}$ M. Sunardi Djiwandono, Tes Bahasa dalam Pengajaran, (Bandung: Penerbit ITB, 
timbal balik antar komponen penyelenggaraan pengajaran semacam itu dapat digambarkan sebagai bersifat bolak balik, seperti dalam gambar berikut ini : ${ }^{9}$

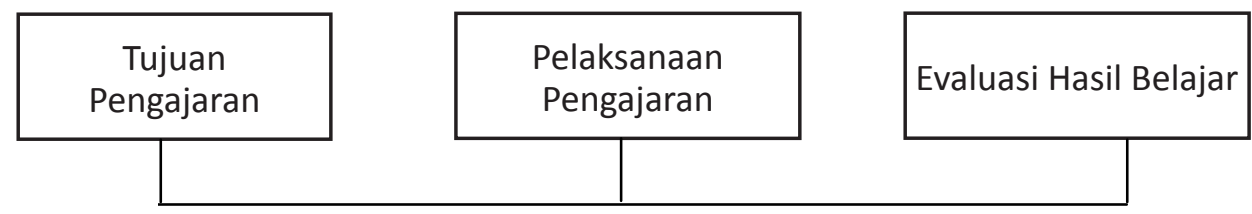

\section{Pengertian Evaluasi dan Jenis-Jenis Evaluasi Pengajaran}

Ada tiga istilah yang perlu dibedakan karena hampir mempunyai pengertian yang berdekatan, yaitu pengukuran, penilaian dan evaluasi. Pengukuran adalah membandingkan sesuatu dengan satu ukuran. Pengukuran biasanya bersifat kuantitatif. Penilaian adalah mengambil suatu keputusan terhadap sesuatu dengan ukuran baik buruk. Penilaian biasanya bersifat kualitatif. Sedang evaluasi mencakup kedua langkah tersebut, yaitu mengukur dan menilai. Dalam istilah Inggrisnya, pengukuran adalah measurement, sedang penilaian adalah evaluation. Dari kata evaluation inilah diperoleh istilah Indonesia evaluasi yang ${ }^{10}$ berarti menilai. ${ }^{11}$

Dalam arti luas, evaluasi adalah suatu proses merencanakan, memperoleh dan menyediakan informasi yang sangat diperlukan untuk membuat alternative-alternatif keputusan. Dengan demikian kegiatan evaluasi merupakan proses yang sengaja direncanakan untuk memperoleh informasi atau data untuk kemudian membuat suatu keputusan. ${ }^{12}$

Tokoh pertama yang mendefinisikan evaluasi berkaitan dengan masalah pendidikan dan prestasi hasil belajar siswa adalah Ralph Tyler (1950) yang mendefinisikan bahwa evaluasi adalah merupakan sebuah proses pengumpulan data untuk menentukan sejauh mana, dalam hal apa, dan bagaimana tujuan pendidikan itu sudah tercapai. Jika belum, bagaimana yang belum dan apa sebabnya. Cron Bach dan Stuffle Beam juga mendefinisikan istilah evaluasi dengan definisi yang hampir sama, dengan

\footnotetext{
1996), h. 3-6

${ }^{9}$ M. Sunardi Djiwandono, Tes Bahasa dalam Pengajaran,h.6 10

${ }^{11}$ Suharsimi Arikunto, Dasar-Dasar Evaluasi Pendidikan, (Jakarta: Bumi Aksara,
} 1995), h. 3

${ }^{12}$ M. Ngalim Purwanto, MP., Prinsip-Prinsip dan Teknik Evaluasi Pengajaran, (Bandung: PT. Rosdakarya, 2004), cet. Ke-12, hlm. 3 
sedikit tambahan bahwa proses evaluasi itu bukan sekedar mengukur sejauhmana tujuan tercapai, tetapi digunakan untuk membuat keputusan. ${ }^{13}$

Dalam kaitannya dengan kegiatan pengajaran, Norman E. Gronlund (1976) - sebagaimana yang dikutip oleh Ngalim Purwanto, MP., dinyatakan bahwa pengertian evaluasi adalah sebagai berikut: "Evaluation.... a systematic process of determining the extent to which instructional objectives are achieved by pupils".(Evaluasi adalah suatu proses yang sistematis untuk menentukan atau membuat keputusan sampai sejauh mana tujuan-tujuan pengajaran bahasa telah tercapai oleh siswa. ${ }^{14}$

Wrightstore dkk. (1950) juga mengemukakan sebagai berikut: "Educational evaluation is the estimation of the growth and progress of pupils toward objectives or values in curriculum" (evaluasi pendidikan adalah penaksiran terhadap pertumbuhan dan kemajuan siswa ke arah tujuantujuan atau nilai-nilai yang telah ditetapkan di dalam kurikulum). ${ }^{15}$

Dari beberapa definisi tersebut setidaknya ada tiga aspek yang perlu diperhatikan berkaitan dengan evaluasi pengajaran, yaitu :

1) Kegiatan evaluasi merupakan proses yang sistematis. Ini berarti bahwa evaluasi merupakan kegiatan yang terencana dan dilakukan secara berkesinambungan. Evaluasi bukan sekedar kegiatan akhir atau penutup suatu program, tetapi merupakan kegiatan yang dilaksanakan di awal, selama program dan pada akhir program pengajaran.

2) Dalam kegiatan evaluasi dibutuhkan berbagai informasi/data yang menyangkut obyek yang sedang dievaluasi. Dalam kaitan dengan pengajaran, data yang dimaksud dapat berupa prilaku/penampilan siswa selama mengikuti pelajaran, hasil ulangan/tugas pekerjaan rumah, nilai ujian akhir catur wulan, nilai mid semester, nilai akhir semester, dan sebagainya.

3) Kegiatan evaluasi pengajaran tidak terlepas dengan tujuan-tujuan pengajaran. Karena setiap kegiatan penilaian memerlukan suatu kriteria tertentu sebagai acuan dalam menentukan batas ketercapaian obyek yang dinilai.

\footnotetext{
${ }^{13}$ Suharsimi Arikunto, Dasar-Dasar Evaluasi Pendidikan, h.3

${ }^{14}$ M. Ngalim Purwanto, Prinsip-Prinsip dan Teknik Evaluasi Pengajaran, $h .3$

${ }^{15}$ M. Ngalim Purwanto, Prinsip-Prinsip dan Teknik Evaluasi Pengajaran, h.3
} 
Dalam kaitannya dengan keseluruhan proses belajar-mengajar, tujuan pengajaran dan prosedur evaluasi, ketiganya tak dapat dipisahkan satu dengan yang lain. Secara jelas dapat digambarkan berikut ini:

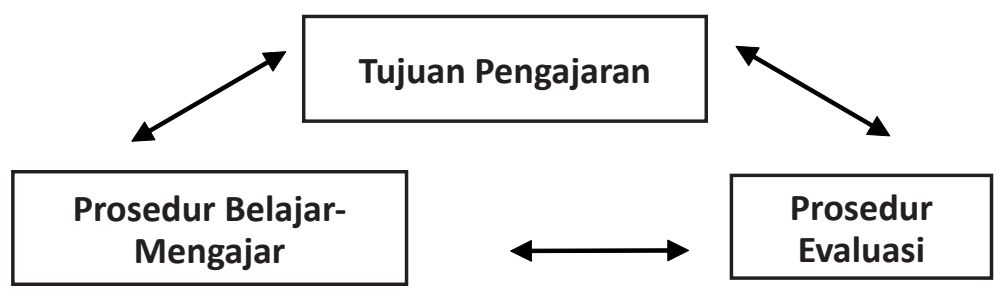

Bahan/materi apa yang akan diajarkan dan metode apa yang akan digunakan bergantung pada tujuan pengajaran yang ingin dicapai. Demikian juga bagaimana prosedur evaluasi harus dilakukan serta bentuk-bentuk tes/alat evaluasi mana yang akan dipakai untuk menilai hasil pengajaran tersebut harus dikaitkan dengan mengacu pada bahan dan metode mengajar yang digunakan dan tujuan pengajaran yang telah dirumuskan.

Berdasarkan jenisnya, evaluasi itu ada empat macam, yaitu: 1). Measurement Model; 2). Congruence Model;3). Educational System Evaluation Model; dan 4). Illuminative Model. ${ }^{16}$ Berikut ini akan penulis jelaskan satupersatu.

\section{Measurement Model}

Model ini dipandang sebagai model tertua dalam sejarah evaluasi yang dikembangkan oleh R. Thorndike dan R.L. Ebel.

Model ini sangat menitik beratkan peranan kegiatan pengukuran dalam melaksanakan proses evaluasi. Pengukuran dipandang sebagai suatu kegiatan yang ilmiah dan dapat diterapkan dalam berbagai bidang persoalan termasuk ke dalamnya bidang pendidikan dan pengajaran. Pengukuran, menurut model ini tidak dapat dilepaskan dari pengertian kuantitas atau jumlah. Jumlah ini akan menunjukkan besarnya (magnitude) obyek, orang ataupun peristiwa yang dilukiskan dalam bentuk unitunit ukuran tertentu seperti misalnya menit, derajat, meter, percentile dan sebagainya, sehingga dengan demikian hasil pngukuran itu selalu dinyatakan dalam bentuk bilangan.

Menurut model ini, evaluasi pada dasarnya adalah pengukuran (measurement) terhadap berbagai aspek tingkah laku dengan tujuan untuk

${ }^{16}$ Daryanto, Evaluasi Pendidikan, (Jakarta: PT. Rineka Cipta, 2001), h.72-99 
melihat perbedaan-perbedaan individual atau kelompok, yang hasilnya diperlukan dalam rangka seleksi, bimbingan, dan perencanaan pendidikan dan pengajaran bagi para siswa di sekolah.

Obyek kegiatan evaluasi model ini adalah tingkah laku siswa, yang mencakup kemampuan hasil belajar, kemampuan pembawaan (intelegensi, bakat), minat, sikap dan juga spek-aspek kepribadian siswa. Singkatnya, obyek evaluasi itu mencakup baik aspek kognitif yang meliputi berbagai tingkat kemampuan seperti kemampuan ingatan, pemahaman aplikasi, dan sebagainya yang evaluasinya dapat dilakukan secara kuantitatif-obyektif dengan menggunakan prosedur yang dapat distandarisasikan. Alat evaluasi yang yang lazim digunakan dalam model evaluasi ini adalah tes tertulis atau paper and pencil test dalam bentuk tes obyektif yang soal-soalnya berupa pilihan ganda, menjodohkan, benar salah, dan sebagainya. ${ }^{17}$

\section{Congruence Model}

Model ini lahir sebagai reaksi dari model pertama di atas. Tokohtokohnya antara lain adalah Raph W. Tyler, John B. Carroll dan Lee J. Cronbach.

Menurut model ini, evaluasi merupakan usaha untuk memeriksa persesuaian (congruence) antara tujuan-tujuan pendidikan dan atau pengajaran yang diinginkan dengan hasil belajar yang telah dicapai. Hasil evaluasi itu berguna untuk kepentingan menyempurnakan sistem bimbingan siswa dan untuk memberikan informasi kepada pihak-pihak di luar pendidikan mengenai hasil-hasil yang telah dicapai. Obyek evaluasi menurut model ini adalah tingkah laku siswa, atau secara khusus, yang dinilai adalah perubahan tingkah laku yang diinginkan (intended behavior) yang diperlihatkan oleh siswa pada akhir pendidikan dan pengajaran. Jadi pertanyaan yang perlu dijawab oleh evaluasi adalah apakah siswa telah mencapai tujuan-tujuan dari sistem pendidikan dan pengajaran melalui kegiatan belajar (learning tasks) yang telah ditempuhnya. Pengertian tingkah laku siswa yang dimaksud adalah tingkah laku hasil belajar yang dicapai siswa.

Tingkah laku hasil belajar tidak hanya terbatas pada segi pengetahuan (kognitif), tapi mencakup dimensi-dimensi lain yang meliputi aspek ketrampilan dan aspek sikap siswa sebagai hasil dari proses

${ }^{17}$ Daryanto, Evaluasi Pendidikan ., h. 75 
pendidikan dan pengajaran. Karena itu model evaluasi ini tidak membatasi alat evaluasi hanya pada tes tertulis atau paper and pencil test saja, tetapi juga digunakan alat evaluasi lain seperti tes perbuatan dan observasi (porto folio). Singkatnya, model evaluasi ini menganut pendirian bahwa berbagai kemungkinan alat evaluasi perlu digunakan, karena hakekat dari tujuantujuan yang ingin dicapailah yang akan menentukan jenis-jenis alat evaluasi yang akan digunakan.

Berhubung yang akan dinilai adalah perubahan tingkah laku siswa setelah menempuh kegiatan pengajaran, maka model ini sangat menekankan perlunya diadakan prosedur pre dan post test untuk menilai hasil yang dicapai siswa sebagai akibat dari kegiatan pendidikan yang telah diikutinya. Sebaliknya, model ini tidak menyarankan diadakannya evaluasi perbandingan untuk melihat sejauh mana kurikulum yang baru lebih efektif dari kurikulum yang ada. Adapun langkah-langkah yang perlu ditempuh dalam proses evaluasi menurut model ini adalah ${ }^{18}$ :

a) Merumuskan atau mempertegas tujuan pengajaran.

b) Menetapkan "test situation" yang diperlukan.

c) Menyusun alat evaluasi yang cocok untuk digunakan untuk menilai jenis-jenis tingkah laku yang tergambar dalam tujuan tersebut.

d) Mengunakan hasil evaluasi.

\section{Educational System Evaluation Model}

Model ketiga ini merupakan reaksi dari kedua model di atas. Tokoh-tokohnya antara lain : Daniel F Stufflebeam, Michael Scriven, Robert E. Stake dan Malcom M. Provus.Menurut model ini, keberhasilan suatu sistem pendidikan dipengaruhi oleh berbagai faktor, karakteristik anak didik maupun lingkungan di sekitarnya, tujuan sistem dan peralatan yang dipakai, serta prosedur dan mekanisme pelaksnaan sistem itu sendiri. Tujuan evaluasi menurut model ini adalah untuk membandingkan performance dari berbagai dimensi sistem yang sedang dikembangkan dengan sejumlah kriteria tertentu, untuk akhirnya sampai pada deskripsi atau judgement mengenai sistem yang dinilai tersebut. ${ }^{19}$

\footnotetext{
${ }^{18}$ Daryanto, Evaluasi Pendidikan., h. 82-83

${ }^{19}$ Daryanto, Evaluasi Pendidikan ., h. 84
} 
Menurut Stufflebeam, sistem pendidikan itu mencakup empat dimensi, yaitu context, input, process, dan product. Karenanya, ke-empat dimensi ini perlu dinilai selama dan pada akhir proses pengembangan kurikulum atau sistem pendidikan. Dengan kata lain, sistem pendidikan itu hendaknya dinilai dari segi latar belakangnya, sarana/rencana kegiatannya, proses pelaksanaanya dan hasil yang dicapainya, agar diperoleh informasi yang luas.Adapun jenis-jenis data yang dikumpulkan dalam kegiatan evaluasi menurut model ini mencakup baik data-data obyektif (skor hasil tes) maupun data-data subyektif atau judgemental data (pandangan guru, reaksi siswa, dan sebagainya). karena itu model evaluasi ini memberikan tempat yang penting bagi pengumpulan judgemental data. ${ }^{20}$

Pendekatan utama model ini antara lain,

a. Perbandingan berdasarkan kriteria intern;

Pendekatanpertamainiditempuhpadasaatsistemmasihberada pada fase pengembangan dan masih mengalami perbaikanperbaikan. Untuk setiap dimensi sistem (input, proses, hasil) dilakukan evaluasi berdasarkan kriteria yang ada :

1) Rencana dinilai berdasarkan kriteria rencana yang baik.

2) Proses (pelaksanaan) dievaluasi dari kesesuaiannya dengan rencana yang ada; rencana kegiatan di sini berlaku sebagai kriteria.

3) Hasil yang dicapai dinilai dari kesesuaiannya dengan tujuan yang ingin dicapai; tujuan di sini berlaku sebagai kriteria. Dalam pendekatan ini, kriteria yang digunakan di atas dipandang sebagai kriteria yang mutlak yang telah dirumuskan sebelumnya.

b. Perbandingan berdasarkan kriteria ekstern;

Pendekatan yang kedua ini ditempuh pada saat sistem berada dalam keadaan "siap" setelah mengalami perbaikan-perbaikan selama fase pengembangan. Dan yang dipertanyakan adalah "apakah sistem yang baru ini lebih baik dari sistem yang ada sekarang".

Untuk melaksanakan kedua pendekatan di atas diperlukan berbagai cara evaluasi di samping tes hasil belajar, yaitu pbservasi, angket, wawancara dan juga content analysis, mengingat data yang dikumpulkan mencakup data obyektif maupun data subyektif (judgemental data).

${ }^{20}$ Daryanto, Evaluasi Pendidikan, h. 89-90 


\section{Illuminative Model}

Model evaluasi ini juga lahir sebagai reaksi dari kedua model evaluasi pertama di atas, yaitu measurement dan congruence. Model ini dikembangkan terutama di Inggris oleh Malcolm Parlett.

Bila model measurement dan congruence lebih berorientasi pada evaluasi secara kuantitatif dan berstruktur, model keempat ini lebih menekankan pada evaluasi kualitatif dan "terbuka". Sistem pendidikan yang dinilai tidak ditinjau sebagai suatu yang terpisah melainkan dalam hubungan dengan suatu learning milieu, dalam kontek sekolah sebagai lingkungan material dan psiko-sosial, yang guru dan muridnya bekerja sama. ${ }^{21}$

Tujuan evaluasi menurut model ini adalah mengadakan studi cermat terhadap sistem yang bersangkutan: bagaimana pelaksanaan sistem tersebut di lapangan, bagaimana pelaksanaan itu dipengaruhi oleh situasi sekolah tempat yang bersangkutan dikembangkan, apa kebaikankebaikan dan kelemahan-kelemahannya dan bagaimana sistem tersebut mempengaruhi pengalaman-pengalaman belajar para siswa. Hasil evaluasi yang dilaporkan lebih bersifat deskripsi dan interpretasi, bukan pengukuran dan prediksi. Oleh karena itu dalam pelaksanaan evaluasi, model ini lebih menekankan pada penggunaan judgement. Singkatnya, dalam mengadakan evaluasi, model ini berpegang pada semboyan bahwa the judgement is the evaluation..$^{22}$

Menurut model ini, obyek evaluasi itu mencakup :

a. Latar belakang dan perkembangan yang dialami oleh sistem yang bersangkutan;

b. Proses pelaksanaan sistem itu sendiri;

c. Hasil belajar yang diperlihatkan siswa;

d. Kesukaran-kesukaran yang dialami dari perencanaan sampai dengan pelaksanaannya di lapangan.

Disamping itu, efek samping dari sistem yang bersangkutan seperti kebosanan yang terlihat pada siswa, ketergantungan secara intelektual, hambatan terhadap perkembangan sikap sosial, dan sebagainya juga menjadi obyek evaluasi model ini. Jadi, obyek evaluasi dari model ini mencakup

${ }^{21}$ Daryanto, Evaluasi Pendidikan, h. 94

${ }^{22}$ Daryanto, Evaluasi Pendidikan., h. 95 
kurikulum yang "terlihat" maupun kurikulum "yang tersembunyi", karena keduanya mempunyai pengaruh yang sama-sama penting.

Berkaitan dengan tujuan dan pendekatan evaluasi yang dianut oleh model keempat ini, kegiatan evaluasi itu dilakukan dalam tiga fase, yaitu :

Pertama, Observe; dalam tahap ini penilai mengunjungi sekolah tempat suatu sistem sedang dikembangkan. Pengevaluasi akan mendengarkan dan melihat berbagai peristiwa, persoalan serta reaksi guru maupun siswa terhadap pelaksanaan sistem tersebut.

Kedua, Inquiry Further; tahap penyeleksian untuk mendapatkan perhatian lebih lanjut. Dengan tujuan agar studi terhadap berbagai persoalan yang telah diseleksi itu menjadi lebih sistematik dan terarah.

Ketiga, Seek to explain; dalam tahap ini penilai mulai meneliti sebab akibat dari masing-masing persoalan. Mulai digali faktor-faktor yang menyebabkan timbulnya persoalan-persoalan tadi. Data-data yang diperoleh secara terpisah dihubungkan dalam kesatuan situasi yang ada pada sekolah tersebut. Lalu dilakukan juga interpretasi terhadap data yang diperoleh, di susun dan dihubungkan dengan berbagai data yang lain. Informasi ini kemudian dijadikan sebagai bahan/input dalam rangka pengambilan keputusan untuk mengadakan perbaikan atau penyesuaian yang diperlukan. ${ }^{23}$

Dalam pengumpulan berbagai data, digunakan berbagai cara, yaitu observasi, wawancara, angket dan analisis bahan-bahan dokumentasi. Alat-alat pengumpulan data yang sifatnya berstruktur, bila masih dapat dihindari, cenderung untuk tidak digunakan. Tes hasil belajar ikut digunakan namun dengan cara yang hati-hati dan hasilnya selalu dianalisis dlam hubungannya dengan data-data yang dihasilkan oleh cara lain. Singkatnya, dalam melaksanakan evaluasi, model ini lebih bersifat terbuka (open-ended), dan dalam melaporkan hasil evaluasi lebih banyak menggunakan cara deskriptif dalam penyajian informasinya. ${ }^{24}$

${ }^{23}$ Daryanto, Evaluasi Pendidikan, h. 97-98

${ }^{24}$ Nana Sudjana, Penelitian dan Penilaian Pendidikan, (Bandung: Sinar Baru, 1988), h. 259. 


\section{Tujuan Evaluasi dan Prinsip-Prinsip Evaluasi Pembelajaran}

Tujuan utama evaluasi dalam proses belajar mengajar adalah untuk mendapatkan informasi yang akurat mengenai tingkat pencapaian kompetensi oleh siswa sesuai indikator yang dirumuskan(tujuan instruksional) sehingga dapat diupayakan tindak lanjutnya. Tindak lanjut yang dimaksud sebagai fungsi evaluasi, dapat berupa :(1). Penempatan pada tempat yang tepat; (2). Pemberian umpan balik; (3). Diagnosis kesulitan belajar siswa, dan (4). Penentuan kelulusan. Karena itu diadakanlah tes yang diberi nama: (1). Tes penempatan(placement test/2), (اختبار تصنيف). Tes formatif(formative test/3), (اختبار تحصيل). Tes diagnostik (diagnostic test), dan (4). Tes sumatif (summative test/اختبار تشخيص).

Menurut M. Ngalim Purwanto, setidaknya ada empat tujuan (sekaligus sebagai fungsi) dari evaluasi pengajaran, yaitu ${ }^{25}$ :

1. Untuk mengetahui kemajuan dan perkembangan serta keberhasilan siswa setelah mengalami atau melakukan kegiatan belajar selama jangka waktu tertentu. Hasil evaluasi yang diperoleh itu selanjutnya dapat digunakan untuk memperbaiki cara belajar siswa (fungsi formatif) dan atau untuk mengisi rapor atau STTB, yang berarti pula untuk menentukan kenaikan kelas atau lulus-tidaknya seorang siswa dari suatu lembaga pendidikan tertentu (fungsi sumatif).

2. Untuk mengetahui tingkat keberhasilan program pengajaran. Pengajaran sebagai suatu system terdiri ata beberapa komponen yang saling berkaitan satu sama lain. Komponen-komponen yang dimaksud antara lain, tujuan, materi/bahan pengajaran, metode dan kegiatan belajar mengajar, alat dan sumber pelajaran, prosedur dan alat evaluasi.

3. Untuk keperluan Bimbingan dan Konseling (BK). Hasil-hasil evaluasi yang telah dilaksanakan oleh guru terhadap siswanya dapat dijadikan sumber informasi atau data bagi pelayanan BK oleh konselor sekolah atau guru BK.

4. Untuk keperluan pengembangan dan perbaikan kurikulum sekolah yang bersangkutan.

Dalam melaksanakan evaluasi harus diperhatikan prinsip-prinsip berikut ini :

${ }^{25}$ M. Ngalim Purwanto, MP., Prinsip-Prinsip dan Teknik Evaluasi Pengajaran, $\mathrm{h}$. 
1. Keterpaduan; evaluasi merupakan komponen integral dalam program pengajaran di samping tujuan instruksional dan materi serta metode pengajaran. Sebagaimana telah dijelaskan di atas, tujuan instruksional, materi dan metode pengajaran dan evaluasi merupakan tiga kesatuan terpadu yang tak boleh dipisahkan. Karenanya perencanaan evaluasi harus sudah ditetapkan waktu menyusun satuan pengajaran sehingga dapat disesuaikan secara harmonis dengan tujuan instruksional dan materi pelajaran yang hendak disajikan.

2. Keterlibatan siswa; Guru harus dapat membangkitkan kegiatankegiatan yang membantu siswa meningkatkan cara dan hasil belajarnya. Evaluasi tidak boleh merisaukan dan menurunkan gairah belajar siswa. Tapi justru sebaliknya, harus dapat meningkatkan mutu dan hasil belajar siswa karena kegiatan evaluasi yang baik itu membantu guru memperbaiki cara mengajar dan membantu siswa dalam meningkatkan cara belajarnya. ${ }^{26}$ Bagi siswa, evaluasi merupakan kebutuhan, bukan sesuatu yang ingin dihindari. Penyajian evaluasi oleh guru merupakan upaya guru untuk memenuhi kebutuhan siswa akan informasi mengenai kemajuan dalam belajar mengajar.

3. Koherensi; maksudnya evaluasi itu harus berkaitan dengan materi pengajaran yang sudah disajikan dan sesuai dengan ranah kemapuan yang hendak diukur. Tidak dibenarkan menyusun alat evaluasi hasil belajar atau evaluasi pencapaian belajar yang mengukur bahan yang belum disajikan dalam kegiatan belajar mengajar.

4. Pedagogis; evaluasi juga perlu diterapkan sebagai upaya perbaikan sikap dan tingkah laku ditinjau dari segi pedagogis. Evaluasi dan hasilnya hendaknya dapat dipakai sebagai alat motivasi untuk siswa dalam kegiatan belajarnya. Hasil evaluasi hendaknya dirasakan sebagai ganjaran/penghargaan (reward) bagi yang berhasil dan hukuman (punishment) bagi yang tidak/kurang berhasil.

Akuntabilitas;keberhasilan program pengajaran perlu disampaikan kepada pihak-pihak yang berkepentingan dengan pendidikan sebagai laporan pertanggungjawaban (accountability). Pihak-pihak yang dimaksud

${ }^{26}$ M. Ngalim Purwanto, MP., Prinsip-Prinsip dan Teknik Evaluasi Pengajaran, h. 
antara lain; orang tua/wali siswa, masnyarakat, sekolah/lembaga pendidikan itu sendiri, dan lain-lain.

\section{E. Media (alat) Evaluasi dan Teknik Evaluasi}

Media atau alat adalah sesuatu yang dapat digunakan untuk mempermudah seseorang dalam melaksanakan tugas atau mencapai tujuan secara efektif dan efisien. Kata "alat" biasa disebut juga dengan istilah "instrument". Dengan demikian alat/media evaluasi juga bisa disebut dengan istilah instrument evaluasi.

Alat evaluasi dapat dikatakan baik bila mampu mengevaluasi sesuatu yang dievaluasi dengan hasil seperti keadaan yang dievaluasi. Dalam menggunakan alat tersebut evaluator menggunakan cara atau teknik, dan oleh karena itu dikenal dengan teknik evaluasi. Teknik evaluasi itu ada dua macam, yaitu teknik non-test dan teknik test.

\section{a. Teknik Non-tes;}

Teknik non-tes merupakan alat penilaian yang dipergunakan untuk mendapatkan informasi tentang keadaan si tertes (tercoba, Inggris: testee) tanpa menggunakan alat tes. Teknik non-tes dipergunakan untuk mendapatkan data yang tidak - atau paling tidak secara tidak langsungberkaitan dengan tingkah laku kognitif. Penilaian yang dilakukan dengan teknik nontes terutama jika informasi yang diharapkan diperoleh berupa tingkah laku afektif, psikomotor, dan lain-lain yang tidak secara langsung berkaitan dengan tingkah laku kognitif.

Teknik non-tes antara lain adalah skala bertingkat (rating scale), kuesioner (questionair), daftar cocok (check list), wawancara (interview), pengamatan (observation), riwayat hidup). ${ }^{27}$ Untuk teknik non-tes ini selanjutnya tidak akan dibicarakan lebih lanjut.

\section{b. Teknik Test;}

Istilah tes berasal dari kata testum (berasal dari bahasa prancis kuno) yang berarti piring untuk menyisihkan logam-logam mulia. Sebelum adanya Ejaan Yang Disempurnakan dalam bahasa Indonesia, tes ditulis dengan test.

Menurut Suharsimi Arikunto, tes merupakan alat atau prosedur yang digunakan untuk mengetahui atau mengukur sesuatu dalam suasana,

${ }^{27}$ Suharsimi Arikunto, Dasar-Dasar Evaluasi..., op. cit, h. 26-31 
dengan cara dan aturan-aturan yang sudah ditentukan. Untuk mengerjakan tes ini tergantung dari petunjuk yang diberikan, misalnya: melingkari salah satu huruf di depan pilihan jawaban, menerangkan, mencoret jawaban yang salah, melakukan tugas atau suruhan, menjawab secara lisan, dan sebagainya.

Menurut Nurkancana dan Sumartana, sebagaimana yang dikutip oleh Burhan Nurgiyantoro dalam bukunya yang berjudul "Penilaian dalam Pengajaran Bahasa dan Sastra", tes adalah suatu cara untuk melakukan penilaian yang berbentuk tugas-tugas yang harus dikerjakan siswa untuk mendapatkan data tentang nilai dan prestasi siswa tersebut yang dapat dibandingkan dengan yang dicapai kawan-kawannya atau nilai standar yang ditetapkan. ${ }^{28}$

Sedangkan dalam Webster's Collegiate disebutkan: "test is any series of questions or other means of measuring the skill, knowledge, intelligence, capacities of aptitudes or an individual or group", ( tes adalah serentetan pertanyaan atau latihan atau alat lain yang digunakan untuk mengukur ketrampilan pengetahuan, intelegensi, kemampuan atau bakat yang dimiliki oleh individu atau kelompok.

Dari tiga definisi tersebut dapat disimpulkan bahwa tekniktes merupakan suatu bentuk pemberian tugas atau pertanyaan yang harus dikerjakan oleh siswa (tercoba, testee) yang sedang dites. Jawaban yang diberikan siswa terhadap pertanyaan-pertanyaan itu dianggap sebagai informasi terpercaya yang mencerminkan kemampuannya. Jika dikaitkan dengan evaluasi yang ada di sekolah, maka tes itu berfungsi untuk mengukur siswa dan mengukur keberhasilan program pengajaran. Alat tes atau instrument tes yang digunakan disekolah biasa disebut dengan soal-soal, entah soal ulangan, soal ulangan umum, soal THB, soal ujian mid semester, soal ujian semester, soal ujian akhir, dan sebagainya.

Tes dapat dibedakan menjadi berbagai macam tergantung dari segi mana kita membedakannya. Dari segi bentuknya tes dibedakan menjadi

${ }^{28}$ Burhan Nurgiyantoro, Penialaian dalam Pengajaran Bahasa dan Sastra, (Yogyakarta: BPFE, 1987), h. 56 
tes0subyektif ${ }^{29}$ dan tes obyektif $\beta^{0}$. Dari segi penyusunannya, jenis tes dibedakan menjadi tes standar ${ }^{31}$ dan tes buatan guru ${ }^{32}$. Bila dilihat dari kegunaannya untuk mengukur keberhasilan atau kemampuan siswa, maka ada empat macam tes, yaitu tes kemampuan awal, ${ }^{33}$ tes diagnosti $k^{34}$, tes formatif ${ }^{35}$ dan tes

${ }^{29}$ Tes Subyektif biasa juga disebut dengan tes essai, yaitu bentuk pertanyaan yang menuntut jawaban siswa dalam bentuk uraian dengan menggunakan bahasanya sendiri. Dalam tes bentuk ini siswa dituntut untuk berfikir tentang dan mempergunakan apa yang diketahui yang berkenaan dengan pertanyaan yang harus dijawab. Tes ini memberikan kebebasan kepada siswa untuk menyusun dan mengemukakan jawabannya sendiri dalam lingkup yang ecara relative dibatasi. Lihat Burhan Nurgiyantoro, Penialaian dalam Pengajaran Bahasa dan Sastra, (Yogyakarta: BPFE, 1987), h. 56 bandingkan dengan M. Ngalim Purwanto, MP., Prinsip-Prinsip dan Teknik Evaluasi Pengajaran, h. 162

${ }^{30}$ Tes Obyektif adalah tes yang hanya menuntut siswa memberikan jawaban singkat, bahkan hanya dengan memilih kode-kode tertentu yang mewakili alternativealternatif jawaban yang telah disediakan.Jawaban terhadap tes bersifat pasti, hanya ada satu kemungkinan jawaban yang benar. Jika siswa tidak menjawab "seperti itu" dinyatakan salah, tidak ada bobot atau skala terhadap jawaban suatu butir soal seperti halnya pada soal essai. Dari segi macamnya, tes obyektif itu ada empat macam, yaitu: Tes Benar-Salah (True-False Test), Tes Pilihan Ganda (Multiple Choice Test), Menjodohkan (Matching Test), dan Tes Isian (Completion Test). Lihat Suharsimi Arikunto, Ibid. h. 164177, lihat juga Moh. Matsna, Teknik Evaluasi Pengajaran Bahasa Arab di Madrasah Tsanawiyah, (makalah Penataran Instruktur/Pembina Guru MTs. Bidang Studi Bahasa Arab di Jakarta), (Jakarta,tidak diterbitkan, 1996), h. 5-15

${ }^{31}$ Tes Standar adalah tes yang telah mengalami proses standarisasi, yaitu proses validasi dan keandalan (reliability) sehingga tes tersebut benar-benar valid dan andal untuk suatu tujuan dan bagi suatu kelompok tertentu. Dengan kata lain, sebagai alat evaluasi, tes tersebut merupakan alat yang jitu dan cermat karena telah mengalami try-out dan perbaikan-perbaikan sehingga akhirnya merupakan tes standar. Tes standar sendiri dapat dibedakan menjadi tes bakat (aptitude test) dan tes prestasi (achievement test). Lihat M. Ngalim Purwanto, MP., Prinsip-Prinsip dan Teknik Evaluasi Pengajaran, (Bandung: PT. Remaja Rosdakarya, 2004), h. 33-34

${ }^{32}$ Tes Buatan Guru adalah tes yang dibuat guru (-guru) kelas itu sendiri. Tes tersebut dimaksudkan untuk mengukur tingkat keberhasilan siswa mencapai tujuan setelah berlangsungnya suatu proses pengajaran yang dikelola oleh guru kelas yang bersangkutan. LihatBurhan Nurgiyantoro, Penialaian dalam Pengajaran Bahasa dan Sastra, (Yogyakarta: BPFE, 1987), h. 58

${ }^{33}$ Tes Kemampuan Awal adalah tes yang dilakukan sebelum siswa mengalami proses belajar mengajar. Tes tersebut mungkin dilakukan sebelum suatu kegiatan belajar mengajar dimulai, atau sebelum siswa memulai pelajaran di lembaga yang bersangkutan. Lihat, Lihat M. Ngalim Purwanto, MP., Prinsip-Prinsip dan Teknik Evaluasi Pengajaran, (Bandung: PT. Remaja Rosdakarya, 2004), h. 62

${ }^{34}$ Tes Diagnostik adalah tes yang digunakan untuk mengetahui kelemahankelamahan siswa sehingga berdasarkan kelemahan-kelamahan tersebut dapat dilakukan pemberian perlakuan yang tepat.

${ }^{35}$ Tes Formatif adalah tes untuk mengetahui sejauhmana siswa telah terbentuk setelah mengikuti sesuatu program/pokok pelajaran tertentu. Dalam kedudukannya 
sumatif. ${ }^{36}$ Tes kemampuan awal sendiri ada tiga macam, yaitu pre-tes ${ }^{37}$, tes prasyarat $^{38}$, dan tes penempatan (placement test) ${ }^{39}$. Bila dilihat dari segi jumlah individu yang dites, tes dapat dibedakan menjadi tes individual dan tes kelompok. Dari segi jawaban yang dikehendaki yang diberikan siswa, tes dapat dibedakan menjadi tes perbuatan dan tes verbal. Tes verbal sendiri, bila dilihat dari cara menjawabnya dibedakan menjadi tes lisan dan tertulis.

Tes subyektif umumnya berbentuk esai (uraian). Tes ini adalah sejenis tes kemajuan belajar siswa yang memerlukan jawaban yang bersifat pembahasan atau uraian kata-kata. Ciri pertanyaannya didahului dengan kata-kata seperti ; uraikan, jelaskan, mengapa, bagaimana, simpulkan, dan sebagainya. Jumlah soal-soal esai biasanya tidak banyak, hanya sekitar 5-10 buah soal untuk dikerjakan dalam waktu 90-120 menit. Soal-soal bentuk esai ini menuntut kemampuan siswa untuk dapat mengorganisir, menginterpretasi, menghubungkan pengertian-pengertian yang telah dimiliki. Selain itu juga menuntut siswa agar dapat mengingat-ingat dan mengenal kembali agar mereka memiliki daya kreativitas yang tinggi. ${ }^{40}$

Dalam menyusun soal esai harus memperhatikan hal-hal berikut ini :

a) Soal-soal tes hendaknya dapat meliputi ide-ide pokok dari bahan yang diteskan, dan kalau mungkin disusun soal yang sifatnya komprehensif.

b) Soal hendaknya tidak mengambil kalimat-kalimat yang disalin langsung dari buku atau catatan.

seperti ini, tes formatif dapat juga dipandang sebagai tes diagnostic pada akhir pelajaran. Tes formatif diberikan diakhir setiap program, sebagai post-tes.

${ }^{36}$ Tes Sumatif adalah tes yang dilaksanakan setelah berakhirnya pemberian sekelompok program atau sebuah program yang lebh besar.

${ }^{37}$ Pre-tes adalah jenis tes kemampuan awal yang dilakukan sebelum siswa mengalami proses belajar dalam suatu pokok bahasan. Pre-tes dimaksudkan untuk mengetahui kemampuan siswa yang berkenaan dengan bahan yang akan dipelajarinya.

${ }^{38}$ Tes Prasyarat adalah tes yang dilakukan sebelum seseorang melakukan (masuk dalam) pendidikan tertentu. Tes dimaksud untuk mengetahui apakah seseorang (siswa) memiliki kemampuan atau ketrampilan tertentu yang disayaratkan untuk mengikuti pendidikan tertentu.

${ }^{39}$ TesPenempatanadalahtesyang dilakukansebelumsiswamemulaipendidikan pada tingkat tertentu. Tes dimaksudkan untuk mengetahui tingkat kemampuan siswa untuk kmudian menempatkannya pada tingkat kemampuan yang sesuai.

${ }^{40}$ Suharsimi Arikunto, Dasar-Dasar Evaluasi Pendidikan, h. 162 
c) Pada waktu menyusun, soal-soal itu sudah dilengkapi dengan kunci jawaban serta pedoman penilaiannya.

d) Hendaknya diusahakan agar pertanyaannya bervariasi antara "jelaskan", "mengapa", bagaimana", "seberapa jauh", agar dapat diketahui lebih jauh penguasaan siswa terhadapbahan.

e) Hendaknya rumusan soal dibuat sedemikian rupa sehingga mudah dipahami oleh tercoba.

f) Hendaknya ditegaskan model jawaban apa yang dikehendaki oleh penyusun tes. Untuk ini pertanyaan tidak boleh terlalu umum, tetapi harus spesifik. ${ }^{41}$

Sedangkan tes obyektif adalah tes yang dalam pemeriksaannya dapat dilakukan secara obyektif. Hal ini dimaksud untuk mengatasi dan menutupi kelemahan-kelemahan tes bentuk esai. Dalam penggunaan tes obyektif ini jumlah soal yang diajukan jauh lebih banyak dari pada tes essai. Kadang-kadang untuk tes yang berlangsung selama 60 menit dapat diberikan 30-40 buah soal. ${ }^{42}$ Adapun tes obyektif itu ada beberapa macam, antara lain :

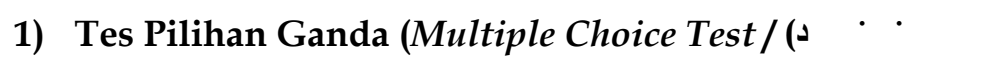

Multiple Choice Test terdiri atas suatu keterangan atau pemberitahuan tentang suatu pengertian yang belum lengkap. Dan untuk melengkapinya harus memilih satu dari beberapa kemungkinan jawaban yang telah disediakan. Atau multiple choice test terdiri atas bagian keterangan (item) dan bagian kemungkinan jawaban atau alternatif (options). Kemungkinan jawaban (options) terdiri atas satu jawaban yang benar yaitu kunci jawaban dan beberapa pengecoh (distractor). ${ }^{43}$

Tes bentuk pilihan ganda ini merupakan bentuk tes obyektif yang paling banyak digunakan karena banyak sekali materi yang dapat dicakup. Bentuk-bentuk soal yang digunakan dalam soal pilihan ganda ada beberapa variasi, antara lain :

a) Pilihan ganda biasa, contohnya :

Pilihlah satu jawaban yang tepat antara A, B, C atau D.

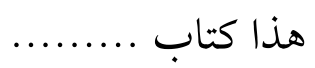

${ }^{41}$ Suharsimi Arikunto, Dasar-Dasar Evaluasi Pendidikan., h. 163-1634

${ }^{42}$ Suharsimi Arikunto, Dasar-Dasar Evaluasi Pendidikan, h. 164

${ }^{43}$ Suharsimi Arikunto, Dasar-Dasar Evaluasi Pendidikan, h. 168 


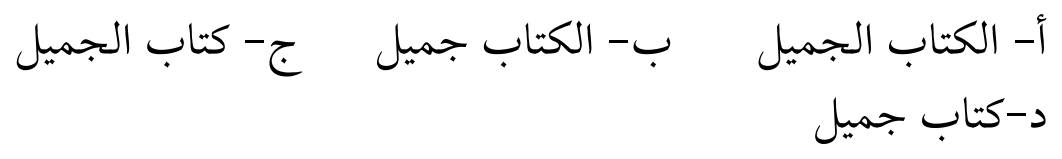

b) Hubungan antar hal (pernyataan - sebab pernyataan), contohnya :

Petunjuk pilihan :

1. Jika penyataan benar, alasan benar, dan keduanya merupakan hubungan sebab akibat.

2. Jika pernyataan benar, alasan benar, dan keduanya bukan merupakan hubungan sebab akibat.

3. Jika pernyataan benar, alasan salah, atau jika pernyataan salah, alasan benar.

4. Jika pernyataan dan alasan keduanya salah.

5. Tulisan Tsanawiyah yang benar adalah : ثناوية

Sebab berasal dari kata اثنين

c) Asosiasi, contohnya :

Petunjuk Pilihan

1. Jika (1), (2), dan (3) betul

2. Jika (1), dan (3) betul

3. Jika (2), dan (4) betul

4. Jika hanya (4) yang betul

5. Jika semuanya betul

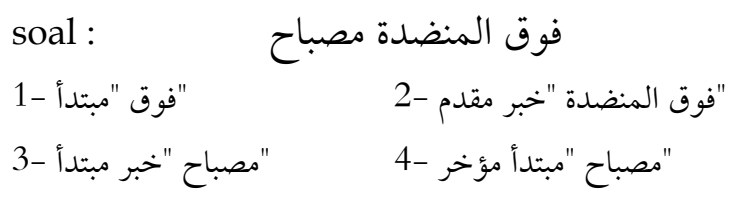

Kedua model terakhir (b dan c di atas) saat ini sangat sulit diterapkan untuk tes bahasa, bahkan kini sudah tidak lagi digunakan karena kurang efektif selain juga kerap kali hanya membingungkan siswa.

Adapun hal-hal yang perlu diperhatikan dalam tes pilihan ganda antara lain;

1. Instruksi pengerjaannya harus jelas, dan bila dipandang perlu disertai contoh mengerjakannya.

2. Dalam tes pilihan ganda hanya ada satu jawaban yang benar. Jadi tidak mengenal tingkatan-tingkatan benar, misalnya benar nomor satu, benar nomor dua, dan sebagainya. 
3. Kalimat pokoknya hendaknya mencakup dan sesuai dengan rangkaian manapun yang dapat dipilih.

4. Kalimat pada tiap butir soal hendaknya sesingkat mungkin.

5. Kalimat pokok dalam setiap butir soal hendaknya tidak tergantung pada butir-butir soal lain.

6. Gunakan kata-kata: "manakah jawaban paling baik, "pilihlah satu yang pasti lebih baik dari yang lain", bilamana terdapat lebih dari satu jawaban yang benar.

7. Dilihat dari segi bahasanya, butir-butir soal jangan terlalu sukar.

8. Tiap butir soal hendaknya hanya mengandung satu ide, meskipun ide tersebut dapat bersifat kompleks.

9. Bila dapat disusun urutan logis antar pilihan-pilihan, urutkanlah (misalnya; urutan tahun, urutan alphabet dan sebagainya).

10. Susunlah agar jawaban manapun mempunyai kesesuaian tata bahasa dengan kalimat pokoknya.

11. Alternatif yang disajikan hendaknya agak seragam dalam panjangnya, sifat uraiannya maupun taraf tehnisnya.

12. Alternatif-alternatif yang disajikan hendaknya agak bersifat homogen mengenai isi dan bentuknya.

13. Buatlah alternatif pilihan ganda sebanyak empat. Bilamana terdapat kesukaran, buatlah pilihan-pilihan tambahan untuk mencapai jumlah empat tersebut. Pilihan-pilihan tambahan hendaknya jangan terlalu gampang diterka karena isinya atau bentuknya.

14. Hindarkan pengulangan suara atau pengulangan kata pada kalimat pokok di alternative-alternatifnya, karena siswa akan cenderung memilih alternatif yang mengandung pengulangan tersebut. Hal ini disebabkan karena dapat diduga itulah jawabannya yang benar.

15. Hindarkan menggunakan susunan kalimat dalam buku pelajaran. Karena yang terungkap mengkin bukan pengertiannya melainkan hafalannya.

16. Alternatif-alternatif hendaknya jangan tumpang tindih, jangan inklusif dan jangan sinonim.

17. Jangan gunakan kata-kata indikator seperti selalu, kadang-kadang, pada umumnya. ${ }^{44}$

${ }^{44}$ Suharsimi Arikunto, Dasar-Dasar Evaluasi Pendidikan, h. 170-172. lihat juga Muhammad Ridla al-Bagdadi, Al-Ahdaf wa al-Ikhtibarat Baina al-Nadhariyyat wa al-Tathbiq fi al-Manahij wa Thuruq al-Tadris, (Kuwait: Maktabah al-Falah, 1984), cet. Ke-2, h. 141-158 
Untuk mengolah skor bentuk tes pilihan ganda digunakan dua rumus, yaitu dengan rumus denda, dan rumus tanpa denda. Bila menggunakan rumus denda, rumusnya adalah

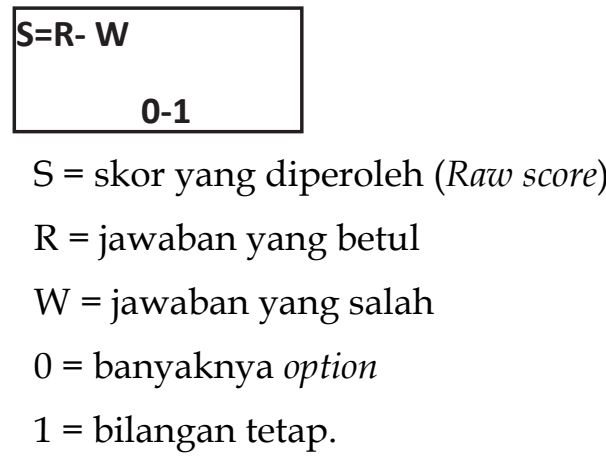

Sedangkan untuk yang tanpa denda mengguakan rumus

$$
\mathbf{S}=\mathbf{R}
$$

2) Tes Benar Salah (True-False Test/اختيار الصواب والخطأ)

Tes benar-salah soal-soalnya berupa pernyataan-pernyataan (statement). Statement tersebut ada yang benar dan ada yang salah. Orang yang ditanya bertugas untuk menandai masing-masing pernyataan dengan melingkari huruf B jika pernyataan itu betul menurut pendapatnya dan melingkari S jika pernyataannya salah. ${ }^{45}$ Contohnya:

$$
\text { ץ- ص- - خ - خ : الكراسة خالد جديدة }
$$

Dalam menyusun tes benar-salah perlu diperhatikan hal-hal berikut ini :

a) Tulisan B-S (ص (-خ) pada permulaan masing-masing item dengan maksud untuk mempermudah mengerjakan dan menilai.

b) Usahakan agar jumlah butir soal yang harus dijawab B sama dengan jumlah butir soal yang harus dijawab S. dalam hal ini hendaknya pola jawaban tidak bersifat teratur, misalnya : B-S-BS-B-S-B-S atau SS-BB-SS-BB-SS.

c) Hindari item yang masih bisa diperdebatkan, contohnya :

d) Hindari pertanyaan-pertanyaan yang persis dengan buku.

${ }^{45}$ Suharsimi Arikunto, Dasar-Dasar Evaluasi Pendidika, h. 166-167 
e) Hindarilah kata-kata yang menunjukkan kecendrungan memberi saran seperti yang dikehendaki oleh item yang bersangkutan, misalnya: semuanya, tidak selalu, tidak pernah, dan sebagainya. ${ }^{46}$

Adapun cara mengolah skor untuk tes benar-salah ada dua cara, yaitu : dengan teknik denda dan tanpa denda. Khusus untuk teknik menskor dengan denda digunakan rumus $\mathrm{S}=\mathrm{R}-\mathrm{W}$, di mana

$$
\begin{aligned}
& \mathrm{S}=\text { skor yang diperoleh } \\
& \mathrm{R}=\text { right (jawaban yang benar) } \\
& \mathrm{W}=\text { wrong (jawaban yang salah). }
\end{aligned}
$$

Sedangkan teknik menskor yang tanpa denda digunakan rumus $\mathrm{S}=\mathrm{R}$, dimana yang dihitung hanya yang betul. Untuk soal yang tidak dikerjakan dinilai nol.

\section{3) Menjodohkan (Matching Test/اختبار المقابلة والمز اوجة)}

Matching test dapat disebut juga dengan mencocokkan, memasangkan, atau menjodohkan. Matching test terdiri atas satu seri pertanyaan dan satu seri jawaban. Masing-masing pertanyaan mempunyai jawaban yang tercantum dalam seri jawaban. Tugas murid ialah mencari dan menempatkan jawaban-jawaban sehingga sesuai atau cocok dengan pertanyaannya. ${ }^{47}$ Contohnya : "Pasangkanlah pertanyaan yang ada pada lajur kanan dengan cara menempatkan huruf yang terdapat di muka pernyataan lajur kiri pada titik-titik yang disediakan di lajur kanan".

Adapun hal-hal yang perlu diperhatikan dalam menyusun tes bentuk matching antara lain :

a) Seri pertanyaan-pertanyaan dalam matching test hendaknya tidak lebih dari 10 soal (item). Sebab, pertanyaan-pertanyaan yang banyak itu akan membingungkan murid. Juga kemungkinan akan mengurangi homogenitas antara item-item itu. Jika itemnya cukup banyak lebih baik dijadikan dua seri.

b) Jumlah jawaban yang harus dipilih harus lebih banyak dari pada jumlah soalnya (kurang lebih 11/2 kali). Dengan demikian murid dihadapakan kepada banyak pilihan, yang semuanya

\footnotetext{
${ }^{46}$ Suharsimi Arikunto, Dasar-Dasar Evaluasi Pendidika, h. 166-167

${ }^{47}$ Suharsimi Arikunto, Dasar-Dasar Evaluasi Pendidikan, h. 172-3
} 
mempunyai kemungkinan benarnya, sehingga murid terpaksa lebih mempergunakan pikirannya.

c) Antara item-item yang tergabung dalam satu seri matching test harus merupakan pengertian-pengertian yang benar-benar homongen. ${ }^{48}$ Misalnya :

$$
\text { أين وجدت كلا من هؤلاء الأفر اد ؟ }
$$

$$
\begin{aligned}
& \text { المكتب -1 } \\
& \text { المدرسة - } 2 \\
& \text { مدرس - }
\end{aligned}
$$

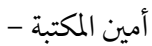

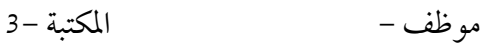

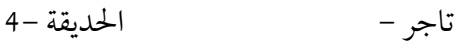

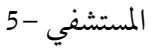

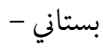

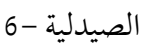

$$
\begin{aligned}
& \text { طبيب }
\end{aligned}
$$

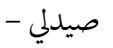

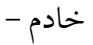

$$
\begin{aligned}
& \text { عامل - مان }
\end{aligned}
$$

Cara mengolah skor soal ini dengan rumus $S=R$, artinya skor terakhir dihitung jawaban yang benar saja.

\section{4) Tes Isian (Completion Test/ (الإختبار بالإجابة الموجزة)}

Completion test biasa juga disebut tes isian, tes menyempurnakan, atau tes melengkapi. Completion test terdiri atas kalimat-kalimat yang ada bagain-bagiannya yang dihilangkan. Bagian yang dihilangkan atau yang harus diisi oleh siswa ini adalah merupakan pengertian yang kita minta dari murid.

Contoh soal :
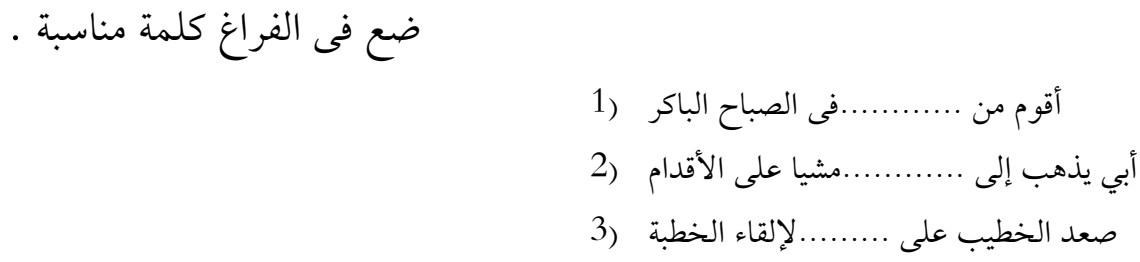

Selain seperti contoh tersebut, dapat pula dibuat dengan kalimatkalimat berangkai dan memuat banyak isian, contohnya :

${ }^{48}$ Suharsimi Arikunto, Dasar-Dasar Evaluasi Pendidikan, h. 174 


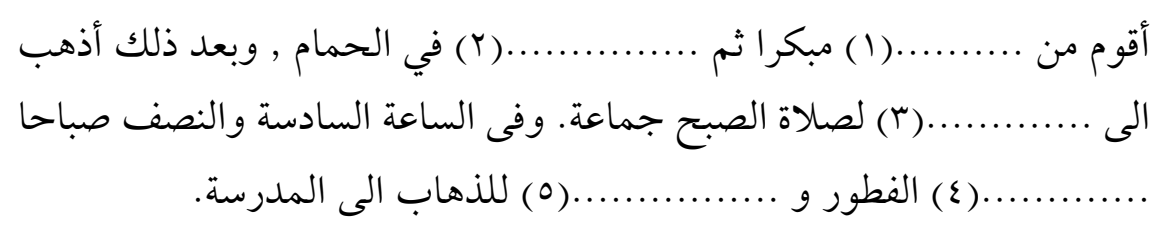

Hal-hal yang perlu diperhatikan dalam penyusunan tes isian antara lain :

a. Perlu selalu diingat bahwa kita dapat merencanakan lebih dari satu jawaban yang kelihatan logis.

b. Jangan mengutip kalimat/pernyataan yang tertera pada buku catatan.

c. Diusahaan semua tempat kosong hendaknya sama panjang.

d. Diusahakan hendaknya setiap pernyataan jangan mempunyai lebih dari satu tempat kosong. ${ }^{49}$

Cara mengolah skornya adalah dengan rumus $S=R$ (sama dengan bentuk matching test.

\section{F. Simpulan}

Dari paparan di atas, dapat disimpulkan bahwa dalam menyusun evaluasi pembelajaran bahasa Arab, guru atau dosen dituntut serius dan mumpuni dalam teori dan praktek karena evaluasi adalah salah satu komponen pembelajaran yang sangat vital dalam kegiatan belajar mengajar. Karena dengan evaluasi bisa diukur sukses tidaknya proses pembelajaran. Dalam merancang alat evaluasi pembelajaran bahasa Arab, evaluator wajib memperhatikan macam evaluasi, tujuan dan prinsip evaluasi, serta ramburambu dalam menyusun teknik tes dan non tes.

\section{DAFTAR PUSTAKA}

Abdullah, Abdul hamid dan Ghaly, Nasr Abdullah, Usus I'dad Kutub al- Ta'limiyyah li Ghairi an-Nathiqin bi al-Arabiyyah, (Kairo: alI'tisaham, tt)

${ }^{49}$ Suharsimi Arikunto, Dasar-Dasar Evaluasi Pendidikan, h. 176 
Abdul Aziz, Musthafa, al-Al'ab al-Lughawiiyah fi Ta'limil Lughat alAjnabiyyah ma' a Amtsilat li Ta'limil 'Arabiyyah li Ghairi al;-Natiqina biha, (ar-Riyah: al-mamlakah al-'Arabiyyah as-Su'udiyah, t,th).

Ahmann, J. Stanley and Glock, Marvin D., Evaluating Pupil Principles of Test and Measurement, (Boston: Allyn and Bacon Growth, 1971)

Arikunto, Suharsimi, Dasar-Dasar Evaluasi Pendidikan, (Jakarta: PT. Bumi Aksara, 2009), cetakan ketiga

-------, Prosedur Penelitian: Suatu Pendekatan Praktek, (Jakarta: Rineke Cipta, 2012), cetakan keduabelas

al-Baghdadi, Muhammad Ridla, Al-Ahdaf wa al-Ikhtibarat Baina alNadhariyyat wa al-Tathbiq fi al-Manahij wa Thuruq al-Tadrisi, (Kuwait: Maktabah al-Falah, tt),

Daryanto, Evaluasi Pendidikan, (Jakarta: PT. Rineka Cipta, 2001).

E. Grounlund, Norman, Measurement and Evaluation in Teaching, (New York: Mac Millan Publishing Co., 1981).

Hindam, Yahya dan Jabir Abdullah Jabir, Al-Manahij: Asasuha, Takhthituha,

Hidayat, H.D., "Pengajaran Bahasa Arab di Indonesia, Masalah dan Cara Mengatasinya", Makalah, (Jakarta: Seminar Pengembangan Pengajaran Bahasa Arab di Indonesia, 1986)

Madkur, Ali Ahmad, Tadrisu Fununil Lughah al-'Arabiyyah, (Kuwait: Maktabul falah, t.th)

Matsna, Muhammad, Tehnik Evaluasi Pengajaran Bahasa Arab: Buku Panduan Penataran Instruktur/Pembina Guru MTs. 1991.

Muhammad, Abdul Khalik Muhammad, Ikhtibarat al-Lugah, (Riyadh: Jami'atu al-Malik Su'ud, 1989)

Muhammad Thobroni, Arif Mustofa, Belajar Dan Pembelajaran, (Yogyakarta: Ar-Ruz Media, 2013)

Nurgiyantoro, Burhan, Penilaian dalam Pengajaran Bahasa dan Saastra, (Yogyakarta: BPFE-Yogyakarta, 1987), cetakan pertama

Nurkacana, Wayan dan PPN. Sumartana, Evaluasi Pendidikan, (Surabaya: PT. Usaha Nasional, 1996).

Purwanto, M. Ngalim, Prinsip-Prinsip dan Tehnik Evaluasi Pengajaran, (Bandung: PT. Rosdakarya, 2004), cetakan keduabelas 
Rozzaq, Sami Mahmud Abdullah, Al-Taqwim al-Tarbawi wa al-Ikhtibarat al-Lughawiyyah, (al-Makhthuth).

Muthawi', et. All, al-Wasail al-Ta'limiyyah, (al-Qahirah: Maktabah Nahdhah al-Misriyyah, t.th)

Sahertian, Piet. A. dan Frans Matuheru, Prinsip dan Tehnik Evaluasi Pendidikan, (Jakarta: PT. Usaha Nasional, 1981).

Sudijono, Anas, Pengantar Evaluasi Pendidikan, (Jakarta: PT. Rajagrafindo, 1997).

Sukiman, Pengembangan Sistem Evaluasi, (Yogyakarta: Insan Madani, 2012)

Suwarna Pringgawidagda, Strategi Penguasaan Berbahasa, (Yogyakarta: Adicita Karya Nusa, 2002)

Thaha, Chabib, Teknik Evaluasi Pendidikan, (Jakarta: PT. RajaGrafindo, 1995) 